\title{
ANALISIS KESULITAN GURU DALAM MELAKSANAKAN PROSES PENILAIAN HASIL BELAJAR BAHASA INDONESIA SESUAI KURIKULUM 2013 DI SMA RK SERDANG MURNI LUBUK PAKAM
}

\author{
NOVI SIJABAT \\ novisijabat22@gmail.com \\ Universitas Katolik Santo Thomas Medan
}

\begin{abstract}
Abstrak. Penelitian ini bertujuan untuk mendeskripsikan kesulitan guru mata pelajaran bahasa Indonesia dalam melaksanakan proses penilaian hasil belajar Bahasa Indonesia sesuai Kurikulum 2013 (K13) di SMA RK Serdang Murni Lubuk Pakam. Penelitian ini dilakukan dengan pendekatan kualitatif dengan metode penelitian deskriptif. Penelitian kualitatif deskriptif ini dilakukan terhadap 3 informan. Berdasarkan hasil penelitian disimpulkan beberapa kesulitan sebagian guru dalam hal: memahami sebagian dokumen, silabus, rencana pelaksanaan pembelajaran (RPP), dan beberapa model pembelajaran K13; pengintegrasian PPK, C4, HOTS, dan literasi dalam RPP; menerapkan penetapan kriteria KKM; pengolahan nilai karena banyaknya kriteria dan indikator; pelaksanaan penilaian sikap dan keterampilan; pelaporan nilai, terutama dalam pelaporan dengan sistem/aplikasi; serta penerapan pemanfaatan dan tindak lanjut hasil penilaian. Solusinya diberi pelatihan dan langsung diterapkan secara konsisten dan kontiniu. Berdasarkan simpulan hasil penelitian, implikasi dari penelitian ini diharapkan dapat dijadikan alternatif dalam mengembangkan pengetahuan, sumbangan pemikiran, dan masukan positif bagi dunia pendidikan khususnya dalam melaksanakan peran sebagai seorang guru dalam mengatasi kesulitan dalam proses penilaian dan pelaporan nilai sesuai K13 pada mata pelajaran bahasa Indonesia. Dalam melaksanakan penelitian ini, peneliti masih memiliki keterbatasan karena pembelajaran dilakukan dengan daring sehingga sulit dilakukan observasi berdampak sebagian data masih kurang akurat, keterbatasan jumlah informan, dan beberapa informan yang kurang serius.
\end{abstract}

\section{Kata Kunci: Kesulitan Guru, Penilaian Hasil Belajar, Kurikulum 2013 (K-13)}

Abstract. This study aims to describe the difficulties of Indonesian language subject teachers in implementing the process of assessing Indonesian learning outcomes according to the 2013 Curriculum (K13) at SMA RK Serdang Murni Lubuk Pakam. This research was conducted with a qualitative approach with descriptive research methods. This descriptive qualitative research was conducted on 3 informants. Based on the results of the study, it was concluded that some teachers had difficulties in terms of: understanding some documents, syllabus, lesson plans (RPP), and some K13 learning models; integrating PPK, C4, HOTS, and literacy into RPP; apply the determination of KKM criteria; processing value because of the many criteria and indicators; implementation of attitude and skills assessment; value reporting, especially in reporting by system / application; as well as implementing the utilization and follow-up of the assessment results. The solution is given training and is immediately applied consistently and continuously. Based on the conclusions of the research results, the implications of this study are expected to be used as an alternative in developing knowledge, contribution of thoughts, and positive input for the world of education, especially in carrying out the role of a teacher in overcoming difficulties in the process of assessing and reporting grades according to K13 in Indonesian subjects. In carrying out this research, researchers still have limitations because learning is carried out online so that it is difficult to make observations as a result of some of the data is still inaccurate, the number of informants is limited, and some informants are not serious.

Keywords: Teacher Difficulties, Assessment of Learning Outcomes, Curriculum 2013 (K-13)

\section{PENDAHULUAN}

Kementerian

Kebudayaan pada

2013/2014 telah

menetapkan kebijakan implementasi

Kurikulum 2013 secara terbatas di 1.270
SMA. Selanjutnya pada tahun pelajaran 2014/2015, Kurikulum 2013 dilaksanakan diseluruh SMA pada kelas X dan XI. Pada tahun 2014 dengan mempertimbangkan masih adanya beberapa kendala teknis, maka berdasarkan Peraturan Menteri 


\section{NOVI SIJABAT \\ ANALISIS KESULITAN GURU DALAM MELAKSANAKAN \\ PROSES PENILAIAN HASIL BELAJAR BAHASA INDONESIA \\ SESUAI KURIKULUM 2013 \\ DI SMA RK SERDANG MURNI LUBUK PAKAM}

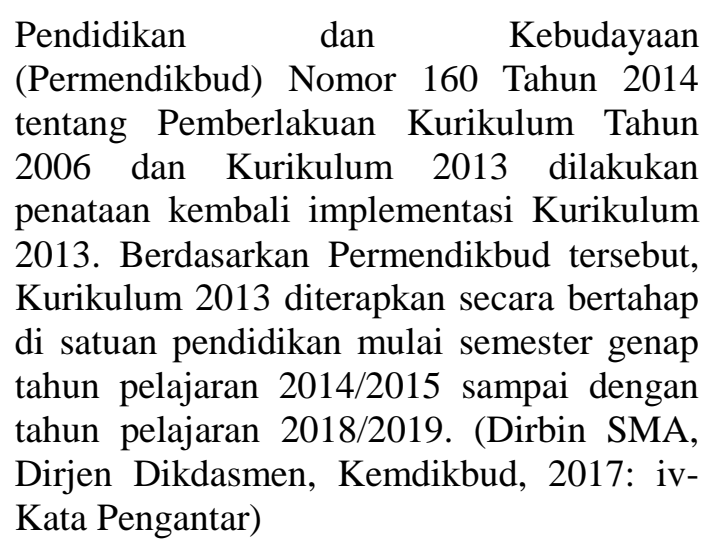

Dalam Kurikulum 2013 guru memiliki peranan penting yaitu sebagai fasilitator. Namun, guru bukanlah satusatunya sumber belajar, guru mendidik dan membimbing peserta didik agar kegiatan pendidikan terlaksana dengan baik, guru yang profesional tidak hanya cukup memenuhi persyaratan administratif, melainkan bagaimana guru dapat memberikan pengertian, pemahaman, dan dapat mendorong peserta didik ke arah aktivitas secara individual terhadap ilmu yang diberikannya. Karena tuntutan sebagai guru dalam implementasi kurikulum seperti di atas itulah sangat wajar guru akan mengalami kesulitan. Hal ini diindikasikan bahwa guru masih bingung dan mengeluhkan bahwa penerapan pembelajaran saintifik dirasakan sangat sulit karena kurangnya pelatihan dan pengetahuan yang dimiliki guru untuk menerapkan Kurikulum 2013 yang menggunakan pembelajaran saintifik pada proses pembelajarannya.. (Kunandar, 2011: 234-235).

Kesulitan yang dialami guru dalam implementasi Kurikulum 2013 adalah beragam. Ini disebabkan karena tingkat pemahaman guru yang berbeda-beda pula dalam mempelajari Kurikulum 2013. Menurut Agnes TutiRumiati selaku Staf Khusus Menteri Pendidikan dan Kebudayaan (Mendikbud) Bidang Pengawasan dan Pengendalian Pembangunan (UKMP3) dalam Dialog dan Konsultasi Nasional terkait Kurikulum 2013 mengungkapkan bahwa ada tiga dimensi kesulitan yang cenderung dialami guru dalam implementasi Kurikulum 2013. Kesulitan itu yaitu terletak pada proses penilaian yang dianggap rumit, penerapan pendekatan scientific dalam kegiatan belajar mengajar, dan mendorong peserta didik untuk aktif dalam pembelajaran.(Agnes TutiRumiati, 2013, news.okezone.com)

\section{METODE PENELITIAN}

Sesuai fokus permasalahan dan tujuan penelitian, pendekatan yang digunakan dalam penelitian ini adalah pendekatan kualitatif. Menurut pandangan penelitian kualitatif, gejala yang timbul dari fokus masalah bersifat holistik. Penelitian kualitatif bersifat holistik (menyeluruh, tidak dapat dipisah-pisahkan), sehingga penelitian kualitatif tidak dapat menetapkan penelitiannya hanya berdasarkan variabel penelitian, tetapi keseluruhan situasi sosial yang diteliti yang meliputi aspek tempat (place), perilaku (actor), dan aktifitas yang berinteraksi secara sinergi. (Sugiyono, 2011: 207)

Dengan demikian jenis penelitian yang digunakan adalah kualitatif deskriptif (descriptive qualitative). Karena pendekatan kualitatif bersifat holistik (menyeluruh), akan dideskripsikansecara menyeluruh berupa kata-kata tertulis dari pernyataan tertulis maupun lisan dari guru-guru tentang bagaimana kesulitan guru dalam melaksanakan proses penilaian hasil belajar Bahasa Indonesia sesuai kurikulum 2013 di SMA RK Serdang Murni Lubuk Pakam.

\section{HASIL DAN PEMBAHASAN \\ 1. Hasil Penelitian}

Penelitian ini dilaksanakan di SMA RK Serdang Murni Lubuk Pakam, yang terletak di jalan Pematang Siantar no 146 Lubuk Pakam. Objek dalam penelitian ini adalah guru di SMA RK Serdang Murni Lubuk Pakam dengan jumlah guru Bahasa Indonesia 3 orang.

Ada 25 pertanyaan yang diajukan kepada setiap guru yang menjadi informan berkaitan dengan implementasi K13 dan Pelaksanaan Proses Penilaian Hasil Belajar Bahasa Indonesia Sesuai Kurikulum 2013 di SMA. Dari 2 informan yang diwawancarai, informan ini hanya beberapa dari 25 pertanyaan dijawab "tidak". Artinya informan tidak terlalu mengalami kesulitan dalam mengimplementasikan Kurikulum 2013 dan Melaksanakan Proses Penilaian Hasil Belajar Bahasa Indonesia Sesuai Kurikulum 2013 di SMA.

Berdasarkan hasil wawancara, ditemukan 10 jenis kesulitan yang dialami guru dalam implementasi Kurikulum 2013 dan Melaksanakan Proses Penilaian Hasil Belajar Bahasa Indonesia Sesuai Kurikulum 2013 di SMA, yaitu:

1) Pembelajaran Kurikulum 2013 revisi 2016, dikarenakan situasi pandemi ini hambatannya adalah karena jaringan yang kurang baik sehingga siswa kurang aktif.

2) Pembelajaran berbasis Saintifik, dikarenakan situasi pandemi ini, hambatannya adalah karena jaringan yang kurang bagus, sehingga siswa kurang peduli dengan pembelajaran. 


\section{NOVI SIJABAT \\ ANALISIS KESULITAN GURU DALAM MELAKSANAKAN \\ PROSES PENILAIAN HASIL BELAJAR BAHASA INDONESIA \\ SESUAI KURIKULUM 2013 \\ DI SMA RK SERDANG MURNI LUBUK PAKAM}

3) Materi yang diterapkan dari buku teks terkadang tidak sesuai dengan yang kita luaskan ke siswa saat siswa melakukan tugasnya di lapangan.

4) Menerapkan model pembelajaran inquiry/discovery. Karena, (a) siswa belum tentu bisa menemukan pembahasan materi yang guru ajarkan, jadi guru harus menyesuaikan model pembelajaran sesuai dengan kebutuhan siswa; (b) tidak semua siswa langsung bisa menangkap semua pembelajaran dengan kemampuan analisis tingkat tinggi.

5) Menerapkan pembelajaran HOTS. Karena guru membuat yang sesuai dengan tingkat tinggi, tapi siswa belum tentu mengerti, karena berbeda-beda tingkat pengetahuan siswa. Jadi ketika siswa belum paham, guru mengulangi pembelajaran tersebut

6) Menerapkan pembelajaran Berbasis Aktivitas. Karena pada masa pandemi masih menggunakan daring. Akan tetapi siswa selalu diberikan tugas. Hambatan nya adalah ketika siswa diberikan tugas proyek, seperti mengamati suatu tempat siswa tidak diperbolehkan keluar rumah.

7) Menerapkan Inkuiri. Siswa disuruh memecahkan suatu masalah, kendalanya yaitu berbedanya latar belakang siswa, jadi ketika guru menyuruh mencari fakta maupun opini dari surat kabar, siswa terkadang tidak bisa menemukan nya, karena tempat tinggal siswa yang berbeda- beda, dan pada umum nyasiswa di SMA RK Serdang Murni Lubuk Pakam berasal dari kampung.

8) Penilaian Keterampilan. Hambatannya adalah ketika siswa diberikan tugas berpidato, penggunaan Bahasanya berbeda-beda tinggal pemahamannya.Pada tabel berikut diuraikan nama-nama informan (guru) yang diwawancarai dan mengisi angket penelitian serta pengalaman setiap informan dari segi lama mengajar, pelatihan, dan seminar yang pernah diikuti.

9) Penilaian Sikap, kendalanya sikap siswa yang berbeda-beda guru harus bekerjasama dengan guru agama, PKN, maupun Guru BK.

10) Penilaian Pengetahuan, karena berbeda-beda tingkat pengetahuannya, berbeda dengan sekolah negeri pada umumnya yang sudah diseleksi, jadi siswa harus diajari sampai siswa benar-benar pintar dan bisa tamat.
Tabel 4.1 Nama Informan Wawancara dan Pengisi Angket Penelitian

\begin{tabular}{|c|c|c|c|c|}
\hline \multirow[b]{2}{*}{ NO. } & \multirow[b]{2}{*}{$\begin{array}{c}\text { NAMA } \\
\text { INFORM } \\
\text { AN/ } \\
\text { GURU }\end{array}$} & \multicolumn{3}{|c|}{ PENGALAMAN } \\
\hline & & $\begin{array}{c}\text { LAMA } \\
\text { MENG } \\
\text { AJAR } \\
\text { (THN) }\end{array}$ & $\begin{array}{c}\text { NAMA } \\
\text { PELATIHA } \\
\text { N }\end{array}$ & $\begin{array}{c}\text { TEMA } \\
\text { SEMINAR }\end{array}$ \\
\hline \multirow[t]{2}{*}{1} & \multirow[t]{2}{*}{$\begin{array}{l}\text { Sahat } \\
\text { Sihombin } \\
\text { g S.Pd }\end{array}$} & \multirow[t]{2}{*}{20} & $\begin{array}{l}\text { 1) Pelatihan } \\
\text { Kurikulum } \\
2013 \\
\end{array}$ & $\begin{array}{l}\text { 1) Seminar } \\
\text { Kurikulum } \\
2013 \\
\end{array}$ \\
\hline & & & $\begin{array}{l}\text { 2) Pelatihan } \\
\text { Soal Hots }\end{array}$ & $\begin{array}{l}\text { 2) Seminar } \\
\text { Soal Hots }\end{array}$ \\
\hline \multirow[t]{2}{*}{2} & \multirow[t]{2}{*}{$\begin{array}{l}\text { Tiarda } \\
\text { Simarmata } \\
\text { S.Pd }\end{array}$} & \multirow[t]{2}{*}{4} & $\begin{array}{l}\text { 1) Pelatihan } \\
\text { Kurikulum } \\
2013 \\
\end{array}$ & $\begin{array}{l}\text { 1) Seminar } \\
\text { Kurikulum } \\
2013 \\
\end{array}$ \\
\hline & & & $\begin{array}{l}\text { 2) Pelatihan } \\
\text { Soal Hots }\end{array}$ & $\begin{array}{l}\text { 2)Seminar } \\
\text { Soal Hots }\end{array}$ \\
\hline
\end{tabular}

\section{SIMPULAN}

Berdasarkan hasil analisis data dari penelitian ini diperoleh simpulan bahwa jenis kesulitan guru adalah:

1) Memahami Dokumen Sesuai Kurikulum 2013 di SMA dalam hal: (1) Rencana Pelaksanaan Pembelajaran (RPP); (2) Karakteristik Pembelajaran HOTS; dan (3) Keterkaitan antara SKL, KI, KD, dan IPK. Diharapkan guru lebih mendalami baik dalam pengertian, karakteristik dalam pembelajaran HOTS dan penyusunan RPP.

2) Memahami Silabus Sesuai Kurikulum 2013 di SMA dalam hal: Komponen Silabus. Diharapkan guru mengikuti atau mengembangan silabus yang sudaah diterapkan dalam sekolah.

3) Penyusunan RPP Sesuai Kurikulum 2013 di SMA dalam hal: Model (Pendekatan/ strategi/metode) pembelajaran. Solusi yang diharapkan adalah guru menyesuaikan materi atau pembelajaran yang dibawakan sesuai dengan model pembelajaran yang ada.

4) Mengimplementasikan Kurikulum 2013 di SMA dalam hal: Strategi Implementasi Keterampilan Abad XXI4 C (Critic, Creative, Collaborative, Communicative). Diharapkan bahwa guru memahami K13 dengan mengikuti kegiatan atau seminar mengenai tentang kurikulum 2013.

5) Memahami Model

(Pendekatan/Strategi/Metode)

pembelajaran di SMA dalam hal: (1) Memahami Karakteristik Model Pembelajaran Berbasis Masalah dan (2) Mengetahui Model-Model Pembelajaran K13. Diharapkan informan memahami dan mengetahui jenis-jenis model pembelajaran dan 


\section{NOVI SIJABAT \\ ANALISIS KESULITAN GURU DALAM MELAKSANAKAN \\ PROSES PENILAIAN HASIL BELAJAR BAHASA INDONESIA \\ SESUAI KURIKULUM 2013 \\ DI SMA RK SERDANG MURNI LUBUK PAKAM}

menyesuiakan dengan materi yang dibawakan.

6) Menerapkan Penetapan Kriteria Ketuntasan Minimal Sesuai K13 Mata Pelajaran Bahasa Indonesia di SMA dalam hal: Pengisian KD, IPK, Kompleksitas KD, Intake, Daya Dukung, dan KKM pada table Penetapan KKM Mata pelajaran. Solusi dari masalah ini diharapkan informan lebih memahami kendala yang dialami dan menerapkan sesuai dengan kemampuan peserta didik. Jika siswa kurang memahami pembelajaran tersebut maka guru mengajari siswa tersebut sapai siswa tersebut benarbenar paham.

7) Memahami dan Melaksanakan Penilaian Keterampilan Sesuai K13 pada Mata Pelajaran Bahasa Indonesia di SMA dalam hal: (1) Tahapan Pelaksanaan Penilaian Proyek dan (2) Pengolahan Penilaian Proyek. Solusi yang diharapkan informan mengetahui bagaimana dalam penilaian yang sesuai dan pengolahan penilaian terhadap peserta didik, baik peserta didik yang tingkat pengetahuan yang tinggi dan rendah.

8) Memahami dan Melaksanakan Penilaian Sikap Sesuai K13 Pada Mata Pelajaran Bahasa Indonesia di SMA dalam hal: Observasi oleh Guru BK dan Wali Kelas. Solusinya adalah Diharapkan informan mengamati secara menyeluruh peserta didik untuk dapat memahami serta penilaian yang sesuai dengan sikap peserta didik.

9) Pengolahan Pelaporan Nilai Hasil Belajar Sesuai K13 pada Mata Pelajaran Bahasa Indonesia di SMA dalam hal: Pengolahan Nilai Keterampilan. Solusi yang diharapkan adalah informan semakin mampu dalam mengelolah nilai yang didapatkan peserta didik sesuai dengan keterampilan yang dimiliki oleh setiap peserta didik.

10) Memahami dan Menerapkan Pemanfaatan dan Tindak Lanjut Hasil Penilaian K13 pada Mata Pelajaran Bahasa Indonesia di SMA dalam hal: Pengayaan. Solusi yang diharapkan adalah informan memahami dan mengetahui karakteristik pengayaan sebelum menerapkan dalam pembelajaran yang dibawakan.

\section{DAFTAR PUSTAKA}

Buku pengembangan dan implementasi kurikulum 2013, Prof. Dr. H.E. Mulyasa, M.Pd
Buku prinsip-prinsip desain pembelajaran disesuaikan dengan kurikulum 2013, Dr. Muhammad Yaumi, M.Hum., MA.

Buku pembelajaran dalam implementasi kurikulum berbasis kompetensi, Prof. Dr. H.WinaSanjaya, M.Pd.

Basiran. 2012. Faktor yang Mempengaruhi Kesulitan dalam Belajar. Jurnal Edukasi Vol. 7, No. 1, 2012.

Departemen Pendidikan Nasional. 2015. Undang-Undang Republik Indonesia Nomor 13 tahun 2015 tentang Standar Nasional Pendidikan. Jakarta: Departemen Pendidikan. Nasional. https://www.kopertis7.go.id I. Diakses pada 2 Juli 2019.

Emzir. 2010. Metodologi Penelitian Kualitatif: Analisis Data. Jakarta: Rajawali Pers.

Fadhly, Fahrus Zaman. 2013. Quo Vadis Kurikulum 2013. http://www.radarcirebon. com/quovadis-kurikulum2013/. Diakses pada 2 Desember 2014.

Fadilallah. 2014. Pendekatan Pembelajaran Saintifik Kurikulum 2013. Bandung: Kementerian Pendidikan dan Kebudayaan. 2013. Pedoman Pelatihan Implementasi Kurikulum 2013. Jakarta: Badan Pengembangan Sumber Daya Manusia Pendidikan dan Kebudayaan dan Penjaminan Mutu Pendidikan.

Kemendikbud. 2005. Undangundang Republik Indonesia No. 14 Tahun 2005 tentang Guru dan Dosen.

Kementerian Pendidikan dan Kebudayaan. 2013. Pedoman Pelatihan Implementasi Kurikulum 2013. Jakarta: Badan 
DI SMA RK SERDANG MURNI LUBUK PAKAM

\author{
Pengembangan Sumber \\ Daya Manusia Pendidikan \\ dan Kebudayaan dan \\ Penjaminan Mutu \\ Pendidik.
}

Khurniawati. 2015. Strategi Guru dalam Menghadapi Kurikulum 2013. Surabaya: Edu Teach

Kunandar. 2008. Guru Profesional Implementasi Kurikulum Tingkat Satuan Pendidikan (KTSP) dan Sukses dalam Sertifikasi Guru. Jakarta: Raja Grafindo. 